\title{
Analysis of Acrylonitrile and a-Methacrylonitrile in Vapor Phase of Mainstream Cigarette Smoke Using a Charcoal Trap for Collection*
}

\author{
by \\ Serban C. Moldoveanu \\ R.J. Reynolds Tobacco Co., 950 Reynolds Blvd., Winston-Salem, NC 27105, USA
}

\section{SUMMARY}

A simple procedure for the collection of vapor phase (VP) of mainstream cigarette smoke for analysis has been developed. This procedure consists of collecting the VP on a commercial charcoal trap $\left(\mathrm{ORBO}^{\mathrm{TM}}-32\right)$ followed by dissolution in acetone. The acetone extract can be analyzed by a gas chromatography/mass spectrometry (GC/MS) technique. A qualitative analysis of the collected VP has been performed for 3R4F Kentucky reference cigarette, allowing the identification of 138 compounds, some compounds being present in both VP and in particulate phase (PP) of cigarette smoke. A quantitative analysis method for acrylonitrile and $\alpha$-methacrylonitrile (2-methyl2-propenenitrile) was also developed, and the level of these compounds in 15 different cigarette brands was measured. Acrylonitrile quantitation was selected since this compound in smoke poses significant health related issues. $\alpha$-Methacrylonitrile quantitation was selected due to the similar structure of this compound with acrylonitrile. The analyzed cigarettes were several Kentucky reference cigarettes including 1R5F, 2R4F, 3R4F, 2R1F, and 1R3F, several King Size (KS) commercial cigarettes from the US market including Basic Non Filter (NF), Basic Ultra Lights (UL), Newport, Marlboro (Red), Marlboro Menthol, Camel Filter, Camel Lights, Camel Ultra Lights, and two herbal cigarettes, Ecstasy and Dreams. The results for acrylonitrile were in very good agreement with data reported in the literature for $2 \mathrm{R} 4 \mathrm{~F}$ and $1 \mathrm{R} 5 \mathrm{~F}$ cigarettes. The levels of $\alpha$ methacrylonitrile were not previously reported. The correlation between the levels of acrylonitrile and of $\alpha$ methacrylonitrile with the (wet) total particulate matter (TPM) was evaluated. Although the levels of acrylonitrile and of $\alpha$-methacrylonitrile in mainstream smoke depend on the TPM values, the correlation is not very strong, indicating that the nature of the cigarette blend and possible other factors in cigarette construction also influence their levels in smoke. The collection method used in this study allows the subsequent dissolution of VP in a much smaller volume of solvent compared to other methods that use impingers, allows the use of standard GC/MS autosamplers for liquid injection and simple addition of internal standards compared to the methods that use gas bags, and allows a simple and immediate collection of VP as it leaves the Cambridge filter pad. These characteristics represent significant advantages versus other methods commonly used for VP analysis. [Beitr. Tabakforsch. Int. 24 (2010) 145-156]

Keywords: Acrylonitrile, $\alpha$-methacrylonitrile, vapor phase of cigarette smoke, GC/MS analysis.

\section{ZUSAMMENFASSUNG}

Es wurde ein einfaches Verfahren zum Auffangen der Gasphase (GP) des Hauptstromrauchs von Zigaretten zu Analysezwecken entwickelt. Dieses Verfahren besteht im Auffangen der GP in einer handelsüblichen Aktivkohlekartusche (ORBO $\left.{ }^{\mathrm{TM}}-32\right)$ und der anschließenden Extraktion mit Aceton. Der Acetonextrakt kann mit Hilfe von Gaschromatographie/Massenspektrometrie (GC/MS) analysiert werden. Eine qualitative Analyse der aufgefangenen GP wurde für die Kentucky-Referenzzigarette 3R4F durchgeführt. Dabei konnten 138 Substanzen identifiziert werden, von denen einige sowohl in der GP als auch in der Partikelphase (PP) des Zigarettenrauchs vorlagen. Eine quantitative Analysemethode für Acrylnitril und $\alpha$-Methacrylnitril (2-Methyl-2-propennitril) wurde ebenfalls entwickelt und die Konzentration dieser Verbindungen in 15 verschiedenen Zigarettensorten bestimmt. Die Quantifizierung von Acrylnitril wurde gewählt, da dieser Rauchbestandteil bedeutende Gesundheitsprobleme verursachen 
kann. $\alpha$-Methacrylnitril wurde aufgrund der dem Acrylnitril ähnlichen Struktur gewählt. Zu den analysierten Zigaretten zählten diverse Kentucky-Referenzzigaretten, darunter 1R5F, 2R4F, 3R4F, 2R1F und 1R3F, diverse auf dem USMarkt erhältliche King-Size-Zigaretten, darunter Basic Non Filter (NF), Basic Ultra Lights (UL), Newport, Marlboro (Red), Marlboro Menthol, Camel Filter, Camel Lights, Camel Ultra Lights sowie zwei Kräuterzigaretten, Ecstasy und Dreams. Die Ergebnisse bezüglich Acrylnitril stimmten sehr gut mit den in der Literatur für 2R4F- und 1R5FZigaretten berichteten Daten überein. Über Konzentrationen von $\alpha$-Methacrylnitril wurden bisher noch nichts publiziert. Die Korrelation zwischen den Konzentrationen von Acrylnitril und $\alpha$-Methacrylnitril und dem (feuchten) Gesamtkondensat (TPM) wurde untersucht. Obwohl die Konzentrationen von Acrylnitril und $\alpha$-Methacrylnitril im Hauptstromrauch von den TPM-Werten abhängen, ist die Korrelation nicht sehr stark und deutet darauf hin, dass die Art der Tabakmischung und mögliche andere Designmerkmale der Zigarette ihre Konzentrationen im Rauch beeinflussen. Die in dieser Untersuchung verwendete Sammelmethode ermöglicht die anschließende Lösung der GP in einem viel geringeren Volumen von Lösungsmittel verglichen mit anderen Methoden, bei denen Impinger zum Einsatz kommen. Sie ermöglicht die Verwendung von Standard-Autosamplern für GC/MS zur Flüssigkeitszugabe und zum einfachen Hinzufügen von internen Standards verglichen mit Gasbeutel-Methoden, und sie ermöglicht das einfache und sofortige Sammeln der GP bei Austritt aus dem Cambridge-Filter. Diese Eigenschaften bieten bedeutende Vorteile gegenüber anderen Methoden, die häufig für die Gasphasenanalyse verwendet werden. [Beitr. Tabakforsch. Int. 24 (2010) 145-156]

\section{RESUME}

Une procédure simple de collecte de la phase vapeur (VP) de la fumée principale de cigarette à des fins d'analyse a été développée. Cette procédure consiste à collecter la VP dans un piège à charbon commercial $\left(\mathrm{ORBO}^{\mathrm{TM}}-32\right)$ puis à la dissoudre dans l'acétone. L'extrait d'acétone peut être analysé par une technique de chromatographie gaz/ spectrométrie de masse (GC/MS). Une analyse qualitative de la VP collectée a été réalisée avec une cigarette de référence Kentucky 3R4F, permettant l'identification de 138 composants, dont certains étaient présents à la fois en VP et en phase particulaire (PP) de la fumée de cigarette. Une méthode d'analyse quantitative de l'acrylonitrile et du améthacrylonitrile (2-méthyl-2-propénénitrile) a également été développée et le taux de ces composants a été mesuré pour 15 marques différentes de cigarettes. La quantification d'acrylonitrile a été choisie car ce composant de la fumée pose des problèmes de santé significatifs. La quantification du composant $\alpha$-méthacrylonitrile a été sélectionnée pour sa structure similaire à celle de l'acrylonitrile. Plusieurs cigarettes de référence Kentucky ont été analysées dont 1R5F, 2R4F, 3R4F, 2R1F et 1R3F, ainsi que plusieurs cigarettes commerciales King Size (KS) du marché américain dont Basic Non Filter (NF), Basic Ultra Lights (UL), Newport, Marlboro (Red), Marlboro Menthol, Camel Filter, Camel Lights, Camel Ultra Lights et deux cigarettes aux plantes Ecstasy et Dreams. Les résultats relatifs à l'acrylonitrile étaient très similaires aux données rapportées dans la littérature pour les cigarettes $2 \mathrm{R} 4 \mathrm{~F}$ et $1 \mathrm{R} 5 \mathrm{~F}$. Les niveaux de $\alpha$-méthacrylonitrile n'avaient pas fait l'objet de rapports au préalable. La corrélation entre les niveaux d'acrylonitrile et de $\alpha$-méthacrylonitrile et le total des particules (humides) (TPM) a été évaluée. Bien que les niveaux d'acrylonitrile et de $\alpha$-méthacrylonitrile dans la fumée principale de cigarette dépendent des valeurs TPM, la corrélation n'est pas très forte, ce qui indique que la nature du mélange de cigarette et d'autres facteurs potentiels dans la fabrication de la cigarette influencent également leurs niveaux dans la fumée. La méthode de collecte utilisée dans cette étude permet la dissolution ultérieure de la VP dans un volume nettement inférieur de solvant comparé à celui d'autres méthodes utilisant des impacteurs. Elle permet d'utiliser des auto-échantillonneurs GC/MS standard pour l'injection de liquide ainsi qu'un simple ajout d'étalons internes comparé aux méthodes utilisant des ballonnets à gaz. Elle permet enfin une collecte simple et immédiate de la VP lorsqu'elle s'échappe du tampon-filtre Cambridge. Ces caractéristiques représentent des avantages significatifs par rapport aux autres méthodes généralement employées pour l'analyse de la VP. [Beitr. Tabakforsch. Int. 24 (2010) 145-156]

\section{INTRODUCTION}

Vapor phase (VP) of mainstream cigarette smoke is a complex mixture of gases and volatile liquids that are not retained when the smoke passes a Cambridge pad. Analysis of VP of cigarette smoke is an important subject since a number of toxicants such as HCN, acetaldehyde, ethylene oxide, and acrylonitrile are VP constituents. Most techniques for the analysis of VP of cigarette smoke depend on the collection in impingers with a solvent (typically also cooled; $1-5)$ or in a Tedlar gas bag $(6,7)$. Other analytical techniques for VP analysis involve cryogenic trapping (with no solvent), trapping on $\operatorname{Tenax}^{\mathbb{B}}(8)$, direct transfer of VP smoke to an analytical instrument (9-12) or even solid phase microextraction (13). Further separation and identification is typically done using GC or GC/MS analysis. Each collection procedure has advantages and disadvantages, related to a number of parameters such as collection efficiency, pressure drop through the impinger(s) when they are installed between the cigarette and the pneumatic panel of the smoking machine, stability of VP smoke components in the gas phase, adsorption on the wall of the Tedlar bag (in case of this type of collection), ease of addition of an internal standard to the sample, degassing in the GC syringe (in case of solvent collection), etc. An alternative procedure for the collection of the VP of cigarette smoke can utilize a charcoal trap $(14,15)$, which allows the quantitative collection of a large number of volatile compounds (16), and has considerable advantages over other collection techniques, as further described. Qualitative analysis of the charcoal trap extract leads to the identification of a considerable number of other components of the VP, with potential for their quantitation. The application of a charcoal trap for sample collection for quantitative purposes is described in this study only for the analysis of 
acrylonitrile and $\alpha$-methacrylonitrile. Acrylonitrile quantitation was selected since this compound in smoke poses significant health related issues. An IARC working group classified acrylonitrile as possibly carcinogenic to humans (Group 2B) based on sufficient evidence in experimental animals (17-19), while the US-EPA classified acrylonitrile as probable human carcinogen based on limited evidence of carcinogenicity in humans (17). For these reasons, the compound is considered a highly undesirable toxicant in smoke (20). On the other hand, $\alpha$ methacrylonitrile is not considered a carcinogen, although it is a known toxicant (21). $\alpha$-Methacrylonitrile quantitation was selected due to the similar structure of this compound with acrylonitrile.

\section{EXPERIMENTAL}

\section{Sampling using a charcoal trap}

For each sample, three cigarettes were smoked using a Borgwaldt rotary machine RM20/CSR (Borgwaldt, 22525 Hamburg, Germany). The particulate phase (PP) of mainstream cigarette smoke was collected on one $92 \mathrm{~mm}$ Cambridge pad. The pad holder was connected to a charcoal trap for the collection of components from the VP, and further to the pneumatic panel of the smoking machine. The trap was an ORBO ${ }^{\mathrm{TM}}$-32 Small trap (Supelco, Bellefonte, PA 16823-0048 USA) containing charcoal in two sections indicated as A and B. Section A of the tube contains $100 \mathrm{mg}$ adsorbent charcoal and is designed to retain the analytes. Section B of the tube contains an additional $50 \mathrm{mg}$ adsorbent charcoal and it is used as backup in case of breakthrough of the analyte. Smoking was done for all samples using $35 \mathrm{~mL}$ puff volume, $2 \mathrm{sec}$ puff duration and $60 \mathrm{sec}$ puff interval (indicated as 35/2/60), similar to Federal Trade Comission (FTC) smoking recommendations for a linear machine (22) and using the measurement of the exhaust flow of the Borgwaldt smoking machine between 4.17 and $4.36 \mathrm{~m} / \mathrm{s}$. Three of the cigarette brands were smoked in more intensive conditions using $60 \mathrm{~mL}$ puff volume, with a puff duration of $2 \mathrm{sec}$ each puff taken at $30 \mathrm{sec}$ interval (indicated as 60/2/30 conditions). The cigarette vent was not blocked in the experiments. After the cigarettes were smoked, one clearing puff was taken.

For each sample, the charcoal from section $\mathrm{A}$ of the $\mathrm{ORBO}^{\mathrm{TM}}-32$ trap was transferred into a $1.5 \mathrm{~mL} \mathrm{GC}$ vial (Agilent, Wilmington, DE 19808, USA), and $1 \mathrm{~mL}$ acetone containing $20 \mu \mathrm{g} / \mathrm{mL}^{2} \mathrm{H}_{3}$-acrylonitrile was added. The ${ }^{2} \mathrm{H}_{3}-$ acrylonitrile was obtained from $\mathrm{CDN}$ Isotopes (PointeClaire, Quebec, H9R 1H1, Canada) and the acrylonitrile (further used for calibration) was obtained from Sigma/Aldrich (St.Louis, MO, 63168, USA). For several samples, the charcoal from section B of the trap was processed similarly. The acetone dissolved immediately the compounds adsorbed in the charcoal. The solution from the vials containing the VP components (without separating the extracted charcoal) was further analyzed by a GC/MS procedure.

The charcoal trap collection procedure is very simple. The $\mathrm{ORBO}^{\mathrm{TM}}-32$ trap can be connected immediately after the Cambridge pad holder and before the pneumatic panel of the smoking machine, avoiding further aging of the VP of cigarette smoke in gas phase. The pressure drop across the $\mathrm{ORBO}^{\mathrm{TM}}-32$ trap is very low, with an average for three measurements of $460 \mathrm{~mm} \mathrm{H} \mathrm{H}_{2} \mathrm{O}(4.51 \mathrm{kPa})$. The use of a solvent for the dissolution of the compounds retained in the trap, allows the addition of internal standards at the desired concentration. However, the volume of the solvent used for the dissolution can be as low as $0.5 \mathrm{~mL}$ (in this study $1.0 \mathrm{~mL}$ solvent was used). This low volume of solvent is much smaller than the volume of solvent typically needed for collection in impingers, such that a more concentrated solution of VP constituents can be obtained compared to impinger collection technique. The use of a liquid injection (as opposed to a gas phase injection) allows the use of standard GC/MS equipment with an autosampler. The procedure does not require special thermal desorption equipment as in the case of adsorption on Tenax ${ }^{\circledR}$.

\section{Sample analysis}

The analysis was performed on a 6890/5973 GC/MS system (Agilent, Wilmington, DE 19808, USA). The separation was performed on a DB-1701 column $60 \mathrm{~m}$, $0.25 \mathrm{~mm}$ internal diameter, and $1 \mu \mathrm{m}$ film thickness (J\&W Scientific from Agilent). The liner used for the injection port of the instrument was single tapered with deactivated glass wool. The operating parameters for the GC/MS instrument are given in Table 1.

A typical chromatogram for a 3R4F cigarette smoked under $35 / 2 / 60$ regimen is shown in Figure 1 . The figure also shows an expanded window containing the extracted ions $\mathrm{m} / \mathrm{z}=56$ corresponding to ${ }^{2} \mathrm{H}_{3}$-acrylonitrile (retention time $16.33 \mathrm{~min}$ ) and $\mathrm{m} / \mathrm{z}=53$ corresponding to acrylonitrile (retention time $16.45 \mathrm{~min}$ ) and 2-methylfuran (retention time $16.63 \mathrm{~min}$ ).

The identification of the peaks in the chromatograms was performed using the data processing capability of the mass spectrometer, and mass spectral libraries Wiley $7 \mathrm{n}$ and NIST02. Also AMDIS_32 (Version 2.1) program with NIST2 mass spectral library were utilized for the identification of compounds in some coeluting peaks. Except for ${ }^{2} \mathrm{H}_{3}$ acrylonitrile, acrylonitrile, and $\alpha$-methacrylonitrile, no other peak in the chromatogram was identified using standards.

\section{Acrylonitrile and $\alpha$-methacrylonitrile quantitation}

The quantitation of acrylonitrile was performed utilizing the ratio of peak area of the ion $\mathrm{m} / \mathrm{z}=53$ of the analyte vs. that of the ion $\mathrm{m} / \mathrm{z}=56$ of the internal standard (extracted ions) using the following formula:

$$
C_{\text {acrylonitrile }}(\mu \mathrm{g} / \mathrm{mL})=\frac{P e a k_{-} \text {area_analyte }}{\text { Peak_area_I.S. }} \cdot C_{I . S .} \cdot F
$$

Where $C$ indicates the concentration (of the sample or of the standard), the concentration of the internal standard being $20 \mu \mathrm{g} / \mathrm{mL}$. $F$ is a response factor for the ratio nondeuterated/deuterated acrylonitrile. This factor was determined by generating calibration curves (compound level) vs. (measured area counts) in the range $0.5 \mu \mathrm{g} / \mathrm{mL}$ to $40 \mu \mathrm{g} / \mathrm{mL}$ of standard solutions for both acrylonitrile and ${ }^{2} \mathrm{H}_{3}$-acrylonitrile using five concentration levels and 
triplicate injections. The dependence equation concentration vs. area for acrylonitrile was:

$C(\mu \mathrm{g} / \mathrm{mL})=7.34697 \mathrm{E}-7 \cdot$ Peak_Area with $\mathrm{R}^{2}=0.99883$ [2]

and the dependence equation for ${ }^{2} \mathrm{H}_{3}$-acrylonitrile was:

$C(\mu \mathrm{g} / \mathrm{mL})=6.77603 \mathrm{E}-7 \cdot$ Peak_Area with $\mathrm{R}^{2}=0.99856[3]$

The slopes ratio of expressions [2] and [3] gave the response factor nondeuterated/deuterated acrylonitrile, with $F=1.0843$.

The calibration curve for $\alpha$-methacrylonitrile was obtained in the range $0.25 \mu \mathrm{g} / \mathrm{mL}$ to $5 \mu \mathrm{g} / \mathrm{mL}$ using four different levels. The quantitation was done using the ion $\mathrm{m} / \mathrm{z}=67$. The dependence equation for $\alpha$-methacrylonitrile was:

$C(\mu \mathrm{g} / \mathrm{mL})=1.20490 \mathrm{E}-6 \cdot$ Peak_Area with $\mathrm{R}^{2}=0.99859[4]$

The quantitation for $\alpha$-methacrylonitrile was done using formula [1] also taking as an internal standard ${ }^{2} \mathrm{H}_{3}$ acrylonitrile, and a response factor $F=1.6399$. The response factor (nondeuterated $\alpha$-methacrylonitrile)/ (deuterated acrylonitrile) is not very close to 1.0, the two compounds having structural differences besides the replacement of hydrogen with deuterium atoms.

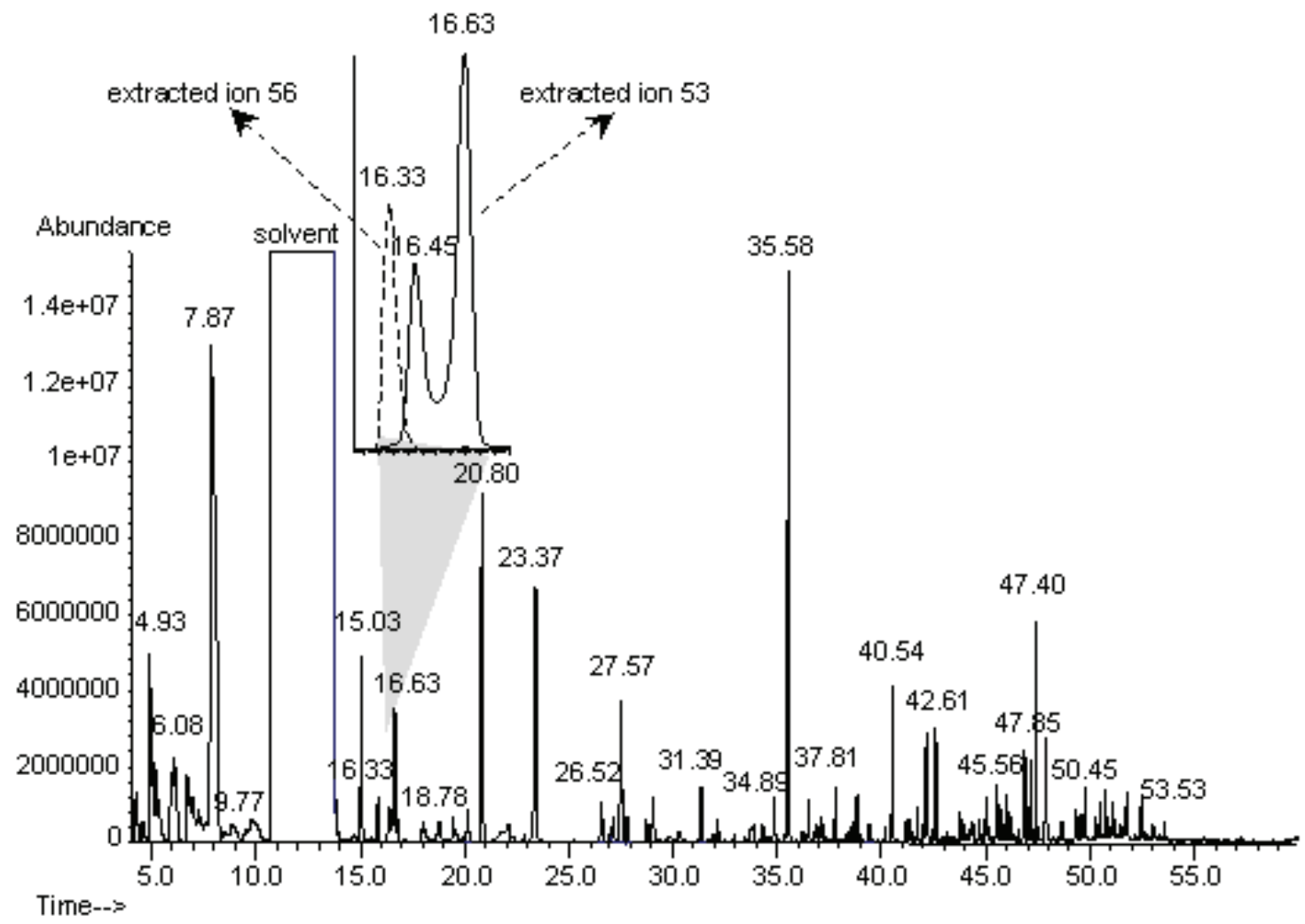

Figure 1. Typical chromatogram for VP from a 3R4F cigarette smoked in 35/2/60 regimen. The expanded window shows the extracted ions $\mathrm{m} / \mathrm{z}=56$ corresponding to ${ }^{2} \mathrm{H}_{3}$-acrylonitrile (retention time $16.33 \mathrm{~min}$ ) and $\mathrm{m} / \mathrm{z}=53$ corresponding to acrylonitrile (retention time $16.45 \mathrm{~min}$ ) and 2-methylfuran (retention time $16.63 \mathrm{~min}$ ).

\section{Validation of acrylonitrile quantitation method}

The method for acrylonitrile analysis was validated for several requirements. The selectivity for the analysis was very good for acrylonitrile, the peak eluting with no interference, although the separation of the extracted ion $\mathrm{m} / \mathrm{z}=53$ for the acrylonitrile peak and for 3-methylfuran was not at the baseline (see Figure 1). The peaks were nevertheless separated enough to not affect the peak area integration by the data processing software of the mass spectrometer. The relative standard deviation of acrylonitrile measurements for a number of 18 samples analyzed in triplicate varied between $0.77 \%$ and $4 \%$ indicating very good precision of the measurement. Repeatability for acrylonitrile analysis could not be evaluated in different matrices since only analysis of smoke was performed. However, the results obtained on 3R4F cigarette by five replicate measurements within a three week period showed a relative standard deviation (RSD\%) of $3.15 \%$.

The accuracy of the procedure was verified for $2 \mathrm{R} 4 \mathrm{~F}$ cigarettes and 1R5F cigarette smoked under 35/2/60 regimen, by comparing the results with the results reported in the literature for a Coresta 2006 Joint Experiment (23). 


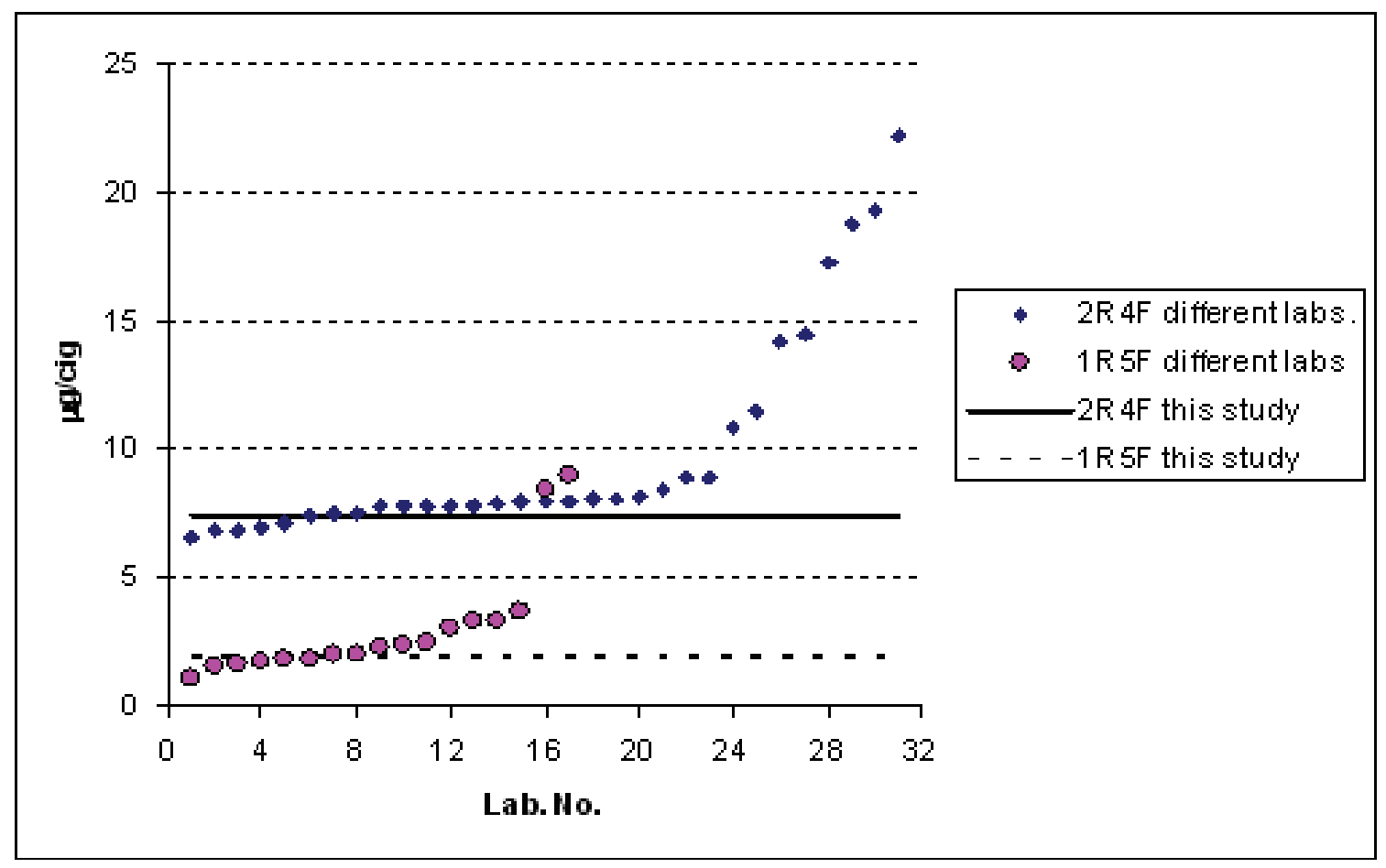

Figure 2. The results for acrylonitrile levels in the smoke of $2 \mathrm{R} 4 \mathrm{~F}$ and $1 \mathrm{R} 5 \mathrm{~F}$ cigarettes (35/2/60 smoking), as reported in the literature (23) and as obtained in the present study.

Figure 2 displays the results reported by different laboratories (23) and the results obtained in this study (as average of triplicate measurement). As seen from Figure 2 the results from the present study are within the range reported by many other laboratories. Also, the results are in good agreement with other reported levels of acrylonitrile in 2R4F cigarette (24).

The linearity of the acrylonitrile measurement was verified in the range $0.5 \mu \mathrm{g} / \mathrm{mL}$ to $40 \mu \mathrm{g} / \mathrm{mL}$, with the trendline showing a $\mathrm{R}^{2}=0.99883$ (see relation [2]). This proves a very good linearity within the specified range.

For the determination of the limit of detection, a standard containing $0.1 \mu \mathrm{g} / \mathrm{mL}$ acrylonitrile was analyzed five times. The results generated a standard deviation $\mathrm{SD}=$ $0.00462 \mathrm{mg} / \mathrm{mL}$. This result would lead to an estimated $\mathrm{LOD}=0.014 \mu \mathrm{g} / \mathrm{mL}$ and an estimated $\mathrm{LOQ}=0.046 \mu \mathrm{g} / \mathrm{mL}$ for the method.

The recovery of the acrylonitrile analysis in VP of cigarette smoke using charcoal trap collection is dependent on two criteria. The first is the retention efficiency of VP in the $\mathrm{ORBO}^{\mathrm{TM}}-32$ trap. For the proof of complete retention of VP components in Section A of the ORBO ${ }^{\mathrm{TM}}-32$ trap, three $3 R 4 F$ cigarettes were smoked using 60/2/30 regimen. After smoking, the analysis of the active charcoal from Section B of the trap was performed in identical conditions as for Section A. The analysis indicated no acrylonitrile present, as well as no other compounds from the VP. The second criteria is related to the completeness of the extraction in acetone of the acrylonitrile from the charcoal. The complete extraction was verified by repeated extraction with three portions of $1 \mathrm{~mL}$ acetone of the same charcoal from Section A of a trap where VP smoke from three 3R4F cigarettes was collected. The solutions were mixed and analyzed. Taking into account the three fold dilution, the difference between single extraction and three repeated extractions (duplicate samples) was within 5\% RSD. The maximum retention capacity of the $\mathrm{ORBO}^{\mathrm{TM}}-32$ trap was not measured, and the completion of the VP retention in extreme conditions such as for a $15 \mathrm{mg}$ 'tar' cigarette smoked under intense regimen was also not verified, since such conditions were not applicable for the cigarettes evaluated in the present study. However, the loading capacity for acetaldehyde is at least $40-50 \mu \mathrm{g}$ for $1 \mathrm{mg}$ charcoal (in the presence of other vapor phase components). This indicated that the ORBO ${ }^{\mathrm{TM}}-32$ small trap can retain without losses the vapor phase smoke from three cigarettes. The retention of VP from ten $3 \mathrm{R} 4 \mathrm{~F}$ cigarettes smoked under 60/2/30 regimen was verified on a ORBO ${ }^{\text {TM}}$-32 Large trap (400 mg charcoal in Section A). The charcoal from Section B or the Large trap did not contain any VP components. The charcoal from Section A was transferred into a $4 \mathrm{~mL}$ vial and extracted with $3 \mathrm{~mL}$ acetone. The results of acrylonitrile quantitation (duplicate samples) were close to the standard procedure for three cigarettes, with less than $10 \%$ deviation. A full validation of the collection of VP smoke in an ORBO ${ }^{\text {TM}}$-32 Large trap was beyond the scope of the present study.

Besides the calibration and verification of linearity in the range $0.25 \mu \mathrm{g} / \mathrm{mL}$ to $5 \mu \mathrm{g} / \mathrm{mL}$ no other validation steps for the $\alpha$-methacrylonitrile quantitation were performed.

\section{RESULTS AND DISCUSSION}

A qualitative analysis of the VP components was performed for 3R4F cigarette. A full list of compounds identified by MS library search is given in Appendix 1. This Appendix 
Table 1. GC/MS operating parameters.

\begin{tabular}{lcc}
\hline Parameter & Description & Parameter \\
\hline Initial oven temperature & $30{ }^{\circ} \mathrm{C}$ & Description \\
Initial time & $11.0 \mathrm{~min}$ & injection volume \\
carrier gas & purge time \\
Oven temperature rate first ramp & $1.5^{\circ} \mathrm{C} / \mathrm{min}$ & purge flow \\
Final temperature first ramp & $60^{\circ} \mathrm{C}$ & flow mode \\
Final time & $0 \mathrm{~min}$ & flow rate \\
Oven temperature rate second ramp & $5.0^{\circ} \mathrm{C} / \mathrm{min}$ & $1.0 \mathrm{~min}$ \\
Final temperature second ramp & $100^{\circ} \mathrm{C}$ & average gas velocity \\
Final time & $1.0 \mathrm{~min}$ & nominal initial pressure \\
Oven temperature rate third ramp & $10^{\circ} \mathrm{C} / \mathrm{min}$ & MSD transfer line \\
Final temperature & $260{ }^{\circ} \mathrm{C}$ & ion source temperature \\
Final time & $4.0 \mathrm{~min}$ & MSD EM offset \\
Total run time & $60 \mathrm{~min}$ & MSD solvent delay \\
Inlet temperature & $26{ }^{\circ} \mathrm{C}$ & MS operating mode \\
Inlet mode & $\mathrm{splitless}$ & mass range a.m.u. \\
\hline
\end{tabular}

Table 2. Selected compounds detected in both VP and PP of mainstream smoke of $3 R 4 F$ cigarette, and their estimated proportion in PP.

\begin{tabular}{l|c|c}
\hline No. & Compound & $\%$ PP \\
\hline 1 & 1,3-Butadiene & 0.21 \\
2 & Acetaldehyde & 0.41 \\
3 & Furan & 0.82 \\
4 & Acetonitrile & 2.84 \\
5 & 2,3-Butanedione & 8.95 \\
6 & Benzene & 1.43 \\
7 & 3-Penten -2-one & 12.14 \\
8 & 2,3-Pentandione & 12.57 \\
9 & Toluene & 3.54 \\
10 & Pyridine & 43.23 \\
11 & o-Xylene & 9.05 \\
12 & p-Xylene & 11.72 \\
13 & 3-Methylpyridine & 61.07 \\
14 & Styrene & 22.09 \\
15 & 2,6-Dimethyl-2,6-octadiene & 33.54 \\
16 & 2-Methyl-2-cyclopenten-1-one & 48.67 \\
17 & Ethyl-3-methylbenzene & 52.80 \\
18 & Limonene & 41.62 \\
19 & Hydroxyacetonitrile & 69.37 \\
20 & Dihydro -2-methyl-3(2H)-furanone & 95.31 \\
21 & Acetic acid & 96.39 \\
22 & Propionic acid & 99.52 \\
23 & 1,2-Propandiol & 99.92 \\
24 & Nicotine & 99.92 \\
\hline
\end{tabular}

also indicates the relative content of a specific compound in vapor phase. This content was calculated exclusively based on the area counts of the peaks in the chromatogram, and cannot be considered quantitative. It gives only an estimate of the peak intensities corresponding to each listed compound. Also, the complexity of the VP of cigarette smoke is considerably higher than indicated by the list of identified compounds. Numerous compounds present at low levels were not considered for identification, although their spectra were frequently very well defined.
Some of the compounds present in VP of cigarette smoke are also found in PP. Table 2 gives a list of selected compounds analyzed in both VP and PP of 3R4F cigarette, and the estimated proportion of each compound present in PP. The calculation was done using the ratios of the peak areas of each individual compound in the chromatogram for the VP and for the PP, the chromatograms being generated using identical conditions as described in Table 1. Many compounds from mainstream cigarette smoke are not included in the list since their detection either in VP or in PP was not feasible. When a compound is below the detection limit for the analytical measurement, the calculation of the true contribution to PP or VP cannot be determined. As seen from Table 2, analysis of some compounds can be done exclusively in VP (or exclusively in PP) since more than $99 \%$ of that compound is present in only one phase, but many compounds are present in both VP and PP.

Further quantitative analysis was performed for acrylonitrile and $\alpha$-methacrylonitrile. These compounds were not detected in the PP of mainstream cigarette smoke. The analysis was performed on several Kentucky reference cigarettes including 1R5F, 2R4F, 3R4F, 2R1F, and 1R3F, several King Size (KS) commercial cigarettes from the US market including Basic Non Filter (NF), Basic Ultra Lights (UL), Newport, Marlboro (Red), Marlboro Menthol, Camel Filter, Camel Lights, Camel Ultra Lights, and two herbal cigarettes, Ecstasy and Dreams. The results were obtained from triplicate sample analyses and are given in Table 3 .

The levels of acrylonitrile and $\alpha$-methacrylonitrile were further compared to the level of total particulate matter (TPM) from the analyzed cigarettes. Figure 3 show the dependence of the levels of acrylonitrile on TPM and Figure 4 shows the dependence for $\alpha$-methacrylonitrile.

Although both acrylonitrile and $\alpha$-methacrylonitrile levels in smoke depend on the TPM of the cigarette, the correlation is not very strong, indicating that the nature of the cigarette blend and possible other factors in cigarette construction also influence the levels of these compounds in smoke. 
Table 3. The levels of acrylonitrile and $\alpha$-methacrylonitrile (in $\mu \mathrm{g} / \mathrm{cig}$ ) in various cigarettes (triplicate samples).

\begin{tabular}{l|c|c|c|c|c|c}
\hline \multirow{2}{*}{ No. } & \multirow{2}{*}{ Cigarette } & \multirow{2}{*}{ Smoking } & \multicolumn{2}{|c|}{ Acrylonitrile } & \multicolumn{2}{c}{$\alpha$-Methacrylonitrile } \\
\cline { 4 - 7 } & & Average & RSD $\%$ & Average & RSD\% \\
\hline 1 & 1R5F & $35 / 2 / 60$ & 1.93 & 3.61 & 0.52 & 2.74 \\
2 & 1R5F & $60 / 2 / 30$ & 9.85 & 4.01 & 2.48 & 0.88 \\
3 & $2 \mathrm{R} 4 \mathrm{~F}$ & $35 / 2 / 60$ & 7.44 & 2.66 & 1.84 & 0.30 \\
4 & 2R4F & $60 / 2 / 30$ & 15.27 & 3.54 & 4.92 & 4.61 \\
5 & 3R4F & $35 / 2 / 60$ & 7.31 & 3.70 & 1.95 & 0.04 \\
6 & 3R4F & $60 / 2 / 30$ & 15.47 & 1.48 & 4.74 & 1.12 \\
7 & 2R1F & $35 / 2 / 60$ & 11.54 & 1.98 & 3.74 & 3.53 \\
8 & 1R3F & $35 / 2 / 60$ & 10.83 & 1.97 & 2.79 & 0.99 \\
9 & Basic NF & $35 / 2 / 60$ & 8.82 & 0.77 & 2.23 & 2.18 \\
10 & Basic UL & $35 / 2 / 60$ & 5.10 & 1.50 & 1.30 & 0.46 \\
11 & Newport & $35 / 2 / 60$ & 13.87 & 0.83 & 3.13 & 2.10 \\
12 & Marlboro & $35 / 2 / 60$ & 10.83 & 2.64 & 2.26 & 2.56 \\
13 & Marlboro Menthol & $35 / 2 / 60$ & 10.77 & 3.06 & 2.23 & 0.86 \\
14 & Camel Filter & $35 / 2 / 60$ & 11.49 & 2.58 & 2.38 & 2.01 \\
15 & Camel Lights & $35 / 2 / 60$ & 9.54 & 3.09 & 1.95 & 2.63 \\
16 & Camel UL & $35 / 2 / 60$ & 4.15 & 1.07 & 0.95 & 0.25 \\
17 & Ecstacy & $35 / 2 / 60$ & 15.82 & 0.83 & 3.72 & 2.66 \\
18 & Dreams & $35 / 2 / 60$ & 6.63 & 3.25 & 1.21 & 0.67 \\
\hline
\end{tabular}

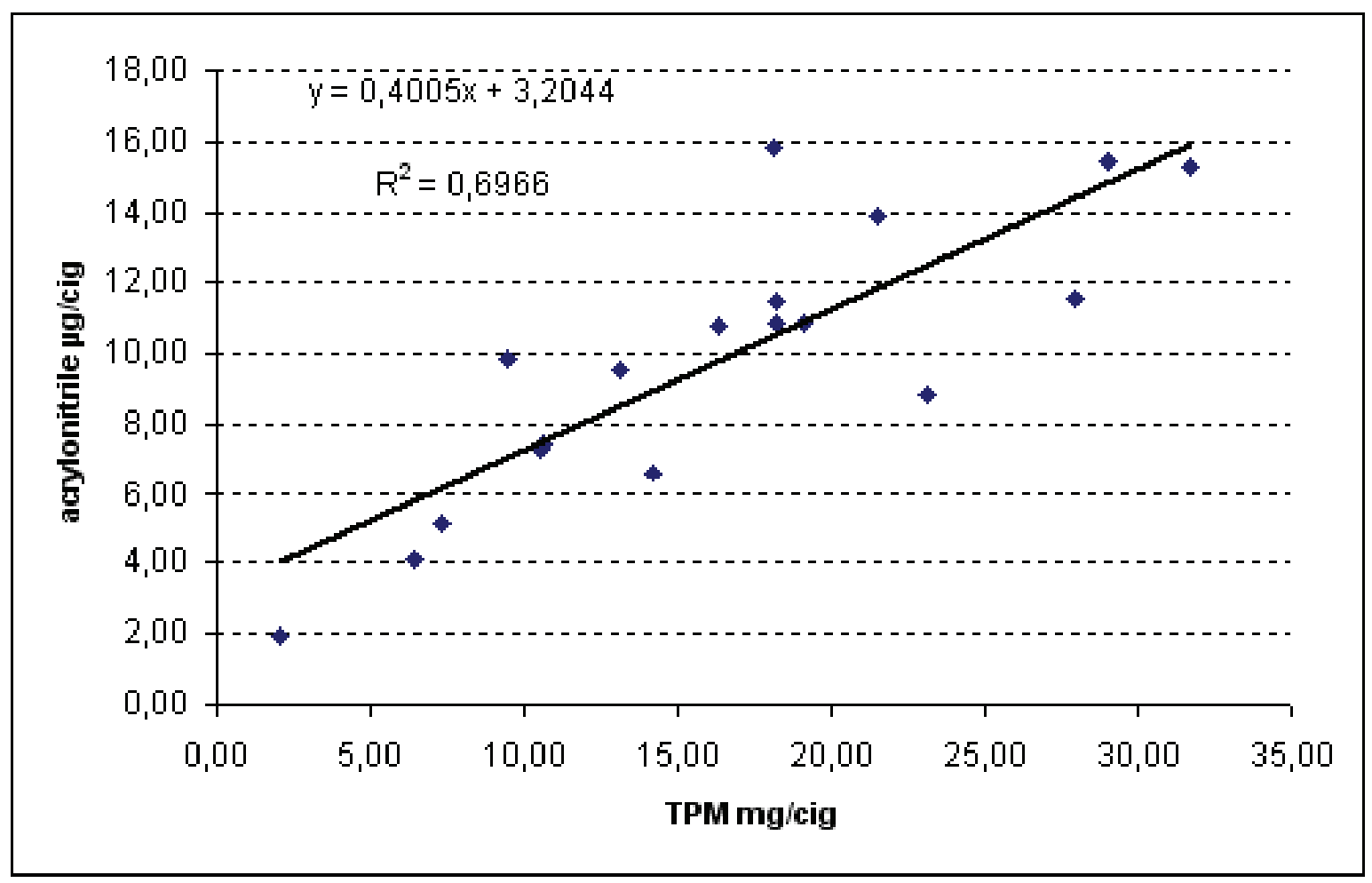

Figure 3. Variation of acrylonitrile in vapor phase cigarette smoke as a function of TPM of the cigarette.

\section{CONCLUSIONS}

A simple procedure for the collection of VP of mainstream cigarette smoke for analysis has been evaluated. This procedure consists of collecting the VP on a commercial charcoal trap (ORBO $\left.{ }^{\text {TM}}-32\right)$ followed by dissolution in acetone and GC/MS analysis. The ORBO ${ }^{\mathrm{TM}}-32$ trap can be connected immediately after the Cambridge pad holder and before the pneumatic panel of the smoking machine, avoiding further aging of the VP of cigarette smoke in gas phase. The pressure drop across the ORBO ${ }^{\mathrm{TM}_{-}} 32$ trap is very low. The use of a solvent for the dissolution of the 
compounds retained in the trap, allows the addition of internal standards at the desired concentration. However, the volume of the solvent used for the dissolution can be as low as $0.5 \mathrm{~mL}$ (in this study $1.0 \mathrm{~mL}$ solvent was used). This low volume of solvent is much smaller than the volume of solvent typically needed for collection in impingers, such that a more concentrated solution of VP constituents can be obtained compared to impinger collection. The use of a liquid injection (as opposed to a gas phase injection) allows the use of standard GC/MS equipment with an autosampler. A qualitative analysis of the collected VP has been performed for 3R4F cigarette smoked under 35/2/60 regimen, allowing the identification of 138 compounds, some present also in PP. A quantitative analysis for acrylonitrile and $\alpha$-methacrylonitrile was also developed, and the level of these compounds in smoke from 15 different cigarette brands was measured. The results for acrylonitrile were in very good agreement with data reported in the literature for $2 \mathrm{R} 4 \mathrm{~F}$ and $1 \mathrm{R} 5 \mathrm{~F}$ cigarettes. The levels of $\alpha$-methacrylonitrile were not previously reported. Although both acrylonitrile and $\alpha$-methacrylonitrile levels in smoke depend on the TPM of the cigarette, the correlation is not very strong, indicating that the nature of the cigarette blend and possible other factors in cigarette construction also influence the levels of these compounds in smoke.

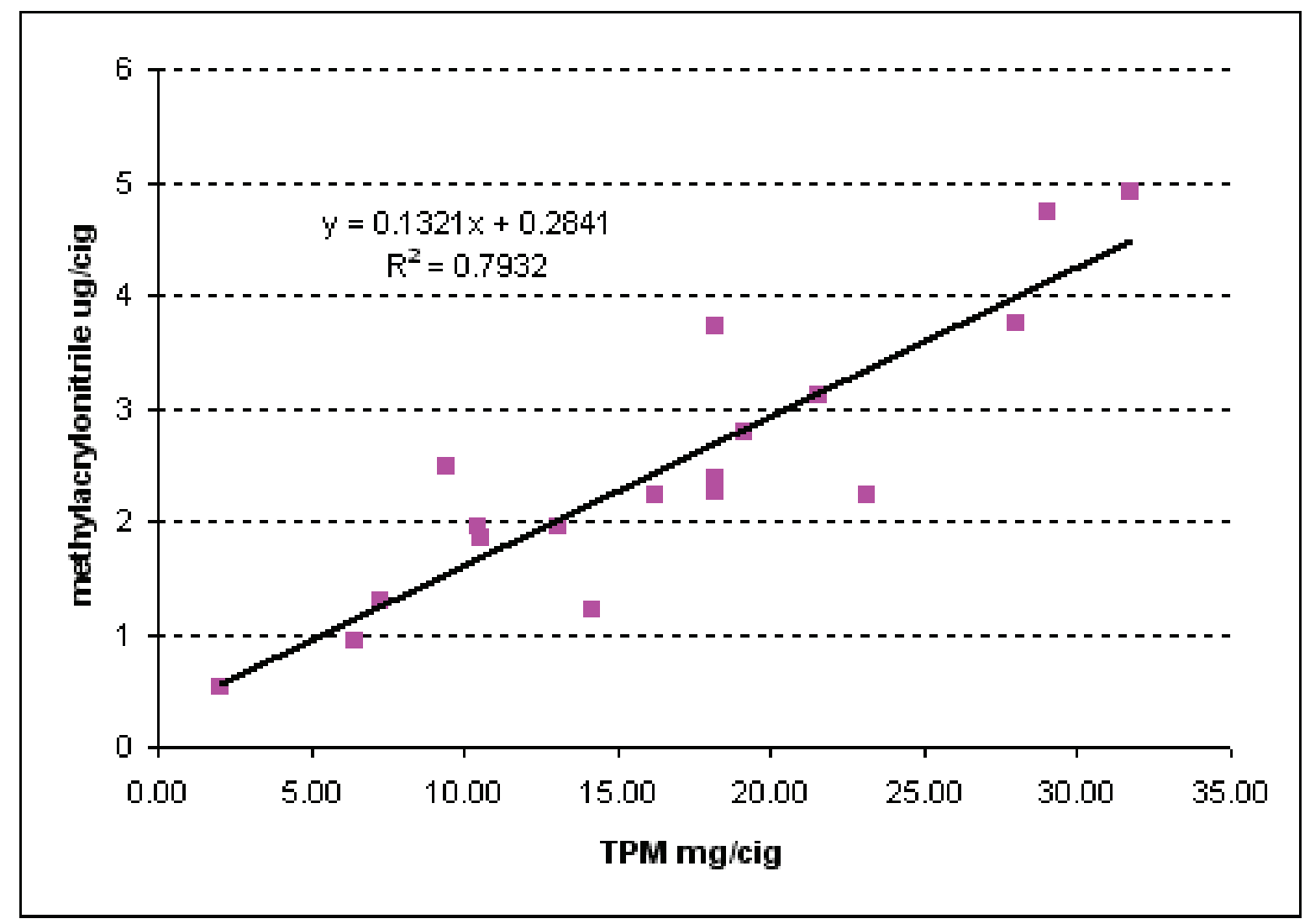

Figure 4. Variation of $\alpha$-methacrylonitrile levels in vapor phase cigarette smoke as a function of TPM of the cigarette.

\section{REFERENCES}

1. Dube, M.F. and C.R. Green: Method for collection of smoke for analytical purposes; Recent Adv. Tob. Sci. 8 (1982) 42-102.

2. Byrd, G.D., K.W. Fowler, R.D. Hicks, M.E. Lovette, and M.F. Borgerding: Isotope dilution gaschromatography-mass spectrometry in the determination of benzene, toluene, styrene, and acrylonitrile in mainstream cigarette smoke; J. Chromatogr. 503 (1990) 359-368.

3. Dong, J.-Z., J.N. Glass, B.T. Thompson, B.F. Price, J.H. Lauterbach, and S.C. Moldoveanu: A simple technique for determining $\mathrm{pH}$ of whole cigarette smoke; Beitr. Tabakforsch. Int. 19 (2000) 33-48.
4. Diekmann, J., C. Biefel, and K. Rustemeier: Analysis of cigarette mainstream smoke for 1,1-dimethylhydrazine and vinyl acetate by gas chromatographymass spectrometry; J. Chromatogr. Sci. 40 (2002) 509-514.

5. Houlgate, P.R., K.S. Dhingra, S.J. Nash, and W.H. Evans: Determination of formaldehyde and acetaldehyde in mainstream cigarette smoke by highperformance liquid chromatography; Analyst, 114 (1989) 355-360.

6. Dong, J.-Z., J.N. Glass, and S.C. Moldoveanu: A simple GC-MS technique for the analysis of vapor phase mainstream cigarette smoke; J. Microcol. Sep. 12 (2000) 142-152.

7. Omori, F., N. Higashi, M. Chida, Y. Sone, and S. 
Suhara: Internal standard-based analytical method for tobacco smoke vapor phase components; Beitr. Tabakforsch. Int. 18 (1999) 131-146.

8. Higgins C.E., W.H. Griest, and G. Olerich: Application of Tenax trapping to analysis of gas phase organic compounds in ultra-low tar cigarette smoke; J. Assoc. Off. Anal. Chem. 66 (1983) 1074-1083.

9. Hatzinikolaou, D.G., V. Lagesson, A.J. Stavridou, A.E. Pouli, L. Lagesson-Andrasko, and J.C. Stavrides: Analysis of the gas phase of cigarette smoke by gas chromatography coupled with UV-diode array detection; Anal. Chem. 78 (2006) 4509-4516.

10. Takanami, Y., M. Chida, H. Hasebe, Y. Sone, and S. Suhara: Analysis of cigarette smoke by an online thermal desorption system and multidimensional GCMS; J. Chromatogr. Sci., 41 (2003) 317-322.

11. Koller, K. and C. Thomas: Puff-by-puff mainstream analysis by multiplex gas chromatography spectrometry; Beitr. Tabakforsch. Int. 19 (2001) 345-351.

12. Wagner K.A., R. Higby, and K. Stutt: Puff-by-puff analysis of selected mainstream smoke constituents in the Kentucky reference 2R4F cigarette; Beitr. Tabakforsch. Int. 21 (2005) 273-279.

13. Ye, Q.: Development of solid-phase microextraction followed by gas chromatography-mass spectrometry for rapid analysis of volatile organic chemicals in mainstream cigarette smoke; J. Chromatogr. A. 1213 (2008) 239-244.

14. Hoffmann, D., C. Patrianakos, K.D. Brunnemann, and G.B. Gori: Chemical studies on tobacco smoke. XXXVI. Chromatographic determination of vinyl chloride in tobacco smoke; Anal. Chem., 48 (1976) 47-50.

15. Moldoveanu, S., W.M. Coleman III, and J. Wilkins: Determination of benzene and toluene in exhaled cigarette smoke; Beitr. Tabakforsch. Int. 23 (2008) 106-113.

16. Moldoveanu, S.C. and V. David: Sample preparation in chromatography; Elsevier, Amsterdam, 2002, ISBN 0444503943.

17. EPA (1991): Integrated risk information system. US Environmental Protection Agency. Summary for acrylonitrile (CASRN 107-13-1), http:/www.epa. gov/ncea/iris/subst/0206.htm (accessed October 2010).

18. IARC (1999): Re-evaluation of some organic chemicals, hydrazine and hydrogen peroxide; Lyon, International Agency for Research on Cancer (IARC Monographs on the Evaluation of Carcinogenic Risks to Humans, Vol. 71).

19. Fennell, T.R., J.P. MacNeela, R.W. Morris, M. Watson, C.L. Thompson, and D.A. Bell: Hemoglobin adducts from acrylonitrile and ethylene oxide in cigarette smokers: effects of glutathione S-transferase T1-null and M1-null genotypes; Cancer Epidemiol. Biomarkers Prev. 9 (2000) 705-712.

20. Hoffmann D. and I. Hoffmann: Tobacco smoke components; Beitr. Tabakforsch. Int. 18 (1998) 49-52.

21. Nyska, A. and B.I. Ghanayem: Characterization of the toxicity, mutagenicity, and carcinogenicity of methacrylonitrile in F344 rats and B6C3F1 mice; Arch. Toxicol. 77 (2003) 233-242.

22. Pillsbury, H.C., C.C. Bright, K.J. O’Connor, and F.H. Irish: Tar and nicotine in cigarette smoke; J. Assoc. Off. Anal. Chem. 52 (1969) 458-462.

23. Intorp, M., S. Purkis, M. Whittaker, and W. Wright: Determination of "Hoffmann Analytes" in cigarette mainstream smoke. The Coresta 2006 Joint Experiment; Beitr. Tabakforsch. Int. 23 (2009) 161-202.

24. Chen, P.X. and S.C. Moldoveanu: Mainstream smoke chemical analyses for 2R4F Kentucky reference cigarette; Beitr. Tabakforsch. Int. 20 (2003) 448-458.

\section{Corresponding author:}

Serban C. Moldoveanu

R.J. Reynolds Tobacco Co.

950 Reynolds Blvd.

Winston-Salem, NC 27105

USA

E-mail: MoldovS@RJRT.com 
Appendix 1. Identification of VP components in the mainstream smoke of 3R4F cigarette. Tentative identifications are indicated by '?'

\begin{tabular}{|c|c|c|c|c|c|}
\hline No. & Compound & Retention time & MW & Formula & $\%$ in VP \\
\hline 1 & Propane & 4.26 & 44 & $\mathrm{C}_{3} \mathrm{H}_{8}$ & 0.36 \\
\hline 2 & Isobutane (2-methylpropane) & 4.59 & 58 & $\mathrm{C}_{4} \mathrm{H}_{10}$ & 0.17 \\
\hline 3 & 2-Butene (E) & 4.93 & 56 & $\mathrm{C}_{4} \mathrm{H}_{8}$ & 2.82 \\
\hline 4 & 2-Butene (Z) & 5.18 & 56 & $\mathrm{C}_{4} \mathrm{H}_{8}$ & 1.08 \\
\hline 5 & 1,3-Butadiene & 5.25 & 54 & $\mathrm{C}_{4} \mathrm{H}_{6}$ & 0.44 \\
\hline 6 & 1-Pentene & 5.94 & 70 & $\mathrm{C}_{5} \mathrm{H}_{10}$ & 1.31 \\
\hline 7 & Acetaldehyde & 6.08 & 44 & $\mathrm{C}_{2} \mathrm{H}_{4} \mathrm{O}$ & 2.83 \\
\hline 8 & 2-Methyl-2-butene & 6.72 & 70 & $\mathrm{C}_{5} \mathrm{H}_{10}$ & 1.56 \\
\hline 9 & 3-Methyl-1-butene & 6.96 & 70 & $\mathrm{C}_{5} \mathrm{H}_{10}$ & 0.87 \\
\hline 10 & 2-Pentene & 7.23 & 70 & $\mathrm{C}_{5} \mathrm{H}_{10}$ & 0.27 \\
\hline 11 & 2-Methyl-1,3-butadiene & 7.87 & 68 & $\mathrm{C}_{5} \mathrm{H}_{8}$ & 22.33 \\
\hline 12 & Furan & 8.53 & 68 & $\mathrm{C}_{4} \mathrm{H}_{4} \mathrm{O}$ & 0.10 \\
\hline 13 & 1,4-Pentadiene & 8.92 & 68 & $\mathrm{C}_{5} \mathrm{H}_{8}$ & 0.11 \\
\hline 14 & 1,3-Cyclopentadiene & 9.77 & 66 & $\mathrm{C}_{5} \mathrm{H}_{6}$ & 0.19 \\
\hline 15 & Acetone (Solvent) & $11.7-13.7$ & 58 & $\mathrm{C}_{3} \mathrm{H}_{6} \mathrm{O}$ & - \\
\hline 16 & Acetic acid methyl ester & 13.82 & 74 & $\mathrm{C}_{3} \mathrm{H}_{6} \mathrm{O}_{2}$ & 7.95 \\
\hline 17 & Acetonitrile & 15.03 & 41 & $\mathrm{C}_{2} \mathrm{H}_{3} \mathrm{~N}$ & 2.18 \\
\hline 18 & 2-Methylpropanal & 15.83 & 72 & $\mathrm{C}_{4} \mathrm{H}_{8} \mathrm{O}$ & 0.63 \\
\hline 19 & d3-Acrylonitrile & 16.33 & 56 & $\mathrm{C}_{3} \mathrm{D}_{3} \mathrm{~N}$ & 0.41 \\
\hline 20 & Acrylonitrile & 16.45 & 53 & $\mathrm{C}_{3} \mathrm{H}_{3} \mathrm{~N}$ & 0.39 \\
\hline 21 & 2-Methylfuran & 16.63 & 82 & $\mathrm{C}_{5} \mathrm{H}_{6} \mathrm{O}$ & 1.77 \\
\hline 22 & 2-Methylpropenal & 16.76 & 70 & $\mathrm{C}_{4} \mathrm{H}_{6} \mathrm{O}$ & 0.31 \\
\hline 23 & 3-Methylfuran & 17.97 & 82 & $\mathrm{C}_{5} \mathrm{H}_{6} \mathrm{O}$ & 0.35 \\
\hline 24 & 2,4-Hexadiene (Z,Z ?) & 18.79 & 82 & $\mathrm{C}_{6} \mathrm{H}_{10}$ & 0.67 \\
\hline 25 & Butanal & 19.42 & 72 & $\mathrm{C}_{4} \mathrm{H}_{8} \mathrm{O}$ & 0.25 \\
\hline 26 & 1-Methyl-1,3-cyclopentadiene & 19.60 & 80 & $\mathrm{C}_{6} \mathrm{H}_{8}$ & 0.15 \\
\hline 27 & Methyl vinyl ketone & 20.11 & 70 & $\mathrm{C}_{4} \mathrm{H}_{6} \mathrm{O}$ & 0.62 \\
\hline 28 & 2-Butanone & 20.80 & 72 & $\mathrm{C}_{4} \mathrm{H}_{8} \mathrm{O}$ & 4.87 \\
\hline 29 & 2,3-Butanedione & 20.89 & 86 & $\mathrm{C}_{4} \mathrm{H}_{6} \mathrm{O}_{2}$ & 1.07 \\
\hline 30 & 1-Heptene & 22.08 & 98 & $\mathrm{C}_{7} \mathrm{H}_{14}$ & 0.36 \\
\hline 31 & Methacrylonitrile & 22.82 & 67 & $\mathrm{C}_{4} \mathrm{H}_{5} \mathrm{~N}$ & 0.12 \\
\hline 32 & Benzene & 23.37 & 78 & $\mathrm{C}_{6} \mathrm{H}_{6}$ & $4 . .86$ \\
\hline 33 & Thiophene & 25.26 & 84 & $\mathrm{C}_{4} \mathrm{H}_{4} \mathrm{~S}$ & 0.01 \\
\hline 34 & 3-Methylbutanal & 26.52 & 86 & $\mathrm{C}_{5} \mathrm{H}_{10} \mathrm{O}$ & 0.71 \\
\hline 35 & 2,4-Hexadienal (E,E ?) & 27.02 & 96 & $\mathrm{C}_{6} \mathrm{H}_{8} \mathrm{O}$ & 0.15 \\
\hline 36 & 2-Methylbutanal & 27.19 & 86 & $\mathrm{C}_{5} \mathrm{H}_{10} \mathrm{O}$ & 0.45 \\
\hline 37 & 2,5-Dimethylfuran & 27.57 & 96 & $\mathrm{C}_{6} \mathrm{H}_{8} \mathrm{O}$ & 2.38 \\
\hline 38 & Isobutyronitrile (1-cyano-1-methylethane) & 27.86 & 69 & $\mathrm{C}_{4} \mathrm{H}_{7} \mathrm{~N}$ & 0.42 \\
\hline 39 & 3-Penten-2-one & 28.78 & 84 & $\mathrm{C}_{5} \mathrm{H}_{8} \mathrm{O}$ & 0.42 \\
\hline 40 & 2-Butenal & 29.09 & 70 & $\mathrm{C}_{4} \mathrm{H}_{6} \mathrm{O}$ & 0.69 \\
\hline 41 & 2-Butenenitrile & 30.27 & 67 & $\mathrm{C}_{4} \mathrm{H}_{5} \mathrm{~N}$ & 0.35 \\
\hline 42 & 1-Pentene-3-one & 31.23 & 84 & $\mathrm{C}_{5} \mathrm{H}_{8} \mathrm{O}$ & 0.05 \\
\hline 43 & 2-Pentanone & 31.39 & 86 & $\mathrm{C}_{5} \mathrm{H}_{10} \mathrm{O}$ & 0.88 \\
\hline 44 & Vinylfuran & 31.97 & 94 & $\mathrm{C}_{6} \mathrm{H}_{6} \mathrm{O}$ & 0.12 \\
\hline 45 & 3-Pentanone & 32.18 & 86 & $\mathrm{C}_{5} \mathrm{H}_{10} \mathrm{O}$ & 0.35 \\
\hline 46 & 2-Methyl-1,5-hexadiene & 32.51 & 96 & $\mathrm{C}_{7} \mathrm{H}_{12}$ & 0.05 \\
\hline 47 & 2,3-Pentanedione & 33.00 & 100 & $\mathrm{C}_{5} \mathrm{H}_{8} \mathrm{O}_{2}$ & 0.11 \\
\hline 48 & 2-Methyl-1-heptene & 33.48 & 112 & $\mathrm{C}_{8} \mathrm{H}_{16}$ & 0.11 \\
\hline 49 & Octane & 33.79 & 114 & $\mathrm{C}_{8} \mathrm{H}_{18}$ & 0.21 \\
\hline 50 & 1-Octene & 33.92 & 112 & $\mathrm{C}_{8} \mathrm{H}_{16}$ & 0.21 \\
\hline 51 & Butanenitrile & 34.33 & 69 & $\mathrm{C}_{4} \mathrm{H}_{7} \mathrm{~N}$ & 0.29 \\
\hline 52 & 2-Methyl-1,6-heptadiene & 34.53 & 110 & $\mathrm{C}_{8} \mathrm{H}_{14}$ & 0.09 \\
\hline 53 & 3-Methylcyclohexanone & 34.73 & 112 & $\mathrm{C}_{7} \mathrm{H}_{12} \mathrm{O}$ & 0.05 \\
\hline 54 & Dimethyldisulfide & 34.89 & 94 & $\mathrm{C}_{2} \mathrm{H}_{6} \mathrm{~S}_{2}$ & 0.59 \\
\hline 55 & 2-Butenenitrile (Isomer?) & 35.46 & 67 & $\mathrm{C}_{4} \mathrm{H}_{5} \mathrm{~N}$ & 0.09 \\
\hline 56 & Toluene & 35.58 & 92 & $\mathrm{C}_{7} \mathrm{H}_{8}$ & 7.21 \\
\hline
\end{tabular}


Appendix 1. (cont.)

\begin{tabular}{|c|c|c|c|c|c|}
\hline No. & Compound & Retention time & MW & Formula & $\%$ in VP \\
\hline 57 & Methyl isobutyl ketone & 36.26 & 100 & $\mathrm{C}_{6} \mathrm{H}_{12} \mathrm{O}$ & 0.11 \\
\hline 58 & 1-Methyl-1H-pyrrole & 36.54 & 81 & $\mathrm{C}_{5} \mathrm{H}_{7} \mathrm{~N}$ & 0.50 \\
\hline 59 & Pyridine & 36.86 & 79 & $\mathrm{C}_{5} \mathrm{H}_{5} \mathrm{~N}$ & 0.26 \\
\hline 60 & 2-Ethyl-5-methylfuran & 37.09 & 110 & $\mathrm{C}_{7} \mathrm{H}_{10} \mathrm{O}$ & 0.25 \\
\hline 61 & 2-Methyl-2-butenal mix & 37.22 & 84 & $\mathrm{C}_{5} \mathrm{H}_{8} \mathrm{O}$ & 0.12 \\
\hline 62 & Octanal & 37.22 & 128 & $\mathrm{C}_{8} \mathrm{H}_{16} \mathrm{O}$ & 0.10 \\
\hline 63 & 2-Methylbutanenitrile mix & 37.81 & 109 & $\mathrm{C}_{5} \mathrm{H}_{9} \mathrm{~N}$ & 0.17 \\
\hline 64 & 1-Cyclopropyl ethanone mix & 37.81 & 84 & $\mathrm{C}_{5} \mathrm{H} 8 \mathrm{O}$ & 0.43 \\
\hline 65 & 2,3,5-Trimethylfuran & 38.40 & 110 & $\mathrm{C}_{7} \mathrm{H}_{10} \mathrm{O}$ & 0.11 \\
\hline 66 & Methyl thiocyanate & 38.63 & 73 & $\mathrm{C}_{2} \mathrm{H}_{3} \mathrm{NS}$ & 0.29 \\
\hline 67 & 3-Methylbutanenitrile & 38.85 & 109 & $\mathrm{C}_{7} \mathrm{H}_{11} \mathrm{~N}$ & 0.51 \\
\hline 68 & ?-Methyl-2-pentenal & 39.05 & 98 & $\mathrm{C}_{5} \mathrm{H}_{10} \mathrm{O}$ & 0.09 \\
\hline 69 & 3-Hexanone & 39.44 & 100 & $\mathrm{C}_{6} \mathrm{H}_{12} \mathrm{O}$ & 0.30 \\
\hline 70 & 3,3,5-Trimethylcyclohexene & 39.53 & 124 & $\mathrm{C}_{9} \mathrm{H}_{16}$ & 0.09 \\
\hline 71 & 2,3-Hexanedione & 39.89 & 114 & $\mathrm{C}_{6} \mathrm{H}_{10} \mathrm{O}_{2}$ & 0.05 \\
\hline 72 & 2-Hexanone & 40.20 & 100 & $\mathrm{C}_{6} \mathrm{H}_{12} \mathrm{O}$ & 0.04 \\
\hline 73 & 4-Methyl-3-penten-2-one & 40.54 & 98 & $\mathrm{C}_{6} \mathrm{H}_{10} \mathrm{O}$ & 1.59 \\
\hline 74 & 3-(1-Methylethyl)cyclopentene & 40.76 & 110 & $\mathrm{C}_{8} \mathrm{H}_{14}$ & 0.03 \\
\hline 75 & 3-(1-Methylethyl)cyclohexene & 41.16 & 124 & $\mathrm{C}_{9} \mathrm{H}_{16}$ & 0.17 \\
\hline 76 & Nonane & 41.30 & 128 & $\mathrm{C}_{9} \mathrm{H}_{20}$ & 00.23 \\
\hline 77 & 1-Nonene & 41.38 & 126 & $\mathrm{C}_{9} \mathrm{H}_{18}$ & 0.19 \\
\hline 78 & 2-Ethyl-1H-pyrrole & 41.52 & 95 & $\mathrm{C}_{6} \mathrm{H}_{9} \mathrm{~N}$ & 0.11 \\
\hline 79 & Cyclopentanone & 41.75 & 84 & $\mathrm{C}_{5} \mathrm{H}_{8} \mathrm{O}$ & 0.34 \\
\hline 80 & 4-Nonene & 42.00 & 126 & $\mathrm{C}_{9} \mathrm{H}_{18}$ & 0.18 \\
\hline 81 & 1,6-Dimethyl-1,3,5-heptatriene & 42.06 & 122 & $\mathrm{C}_{9} \mathrm{H}_{14}$ & 0.22 \\
\hline 82 & Ethylbenzene & 42.16 & 106 & $\mathrm{C}_{8} \mathrm{H}_{10}$ & 0.93 \\
\hline 83 & 1,6-Dimethyl-1,3,5-heptatriene isomer & 42.24 & 122 & $\mathrm{C}_{9} \mathrm{H}_{14}$ & 0.17 \\
\hline 84 & 1-(2-Furanyl)-1-propanone & 42.47 & 124 & $\mathrm{C}_{7} \mathrm{H}_{8} \mathrm{O}_{2}$ & 0.11 \\
\hline 85 & o-Xylene & 42.61 & 106 & $\mathrm{C}_{8} \mathrm{H}_{10}$ & 1.23 \\
\hline 86 & 2-Methyl-2-pentenal & 43.18 & 98 & $\mathrm{C}_{6} \mathrm{H}_{10} \mathrm{O}$ & 0.09 \\
\hline 87 & 2,4-Dimethyl-2,4-heptadiene & 43.33 & 124 & $\mathrm{C}_{9} \mathrm{H}_{16}$ & 0.04 \\
\hline 88 & 2-Methylcyclopentanone & 43.77 & 98 & $\mathrm{C}_{6} \mathrm{H}_{10} \mathrm{O}$ & 0.23 \\
\hline 89 & p-Xylene & 43.90 & 106 & $\mathrm{C}_{8} \mathrm{H}_{10}$ & 0.19 \\
\hline 90 & 3,7-Dimethyl-1,6-octadiene & 44.05 & 138 & $\mathrm{C}_{10} \mathrm{H}_{18}$ & 0.03 \\
\hline 91 & 3-Methylpyridine & 44.23 & 93 & $\mathrm{C}_{6} \mathrm{H}_{7} \mathrm{~N}$ & 0.04 \\
\hline 92 & Styrene & 44.29 & 104 & $\mathrm{C}_{8} \mathrm{H}_{8}$ & 0.12 \\
\hline 93 & 3-Methylcyclopentanone & 44.39 & 98 & $\mathrm{C}_{6} \mathrm{H}_{10} \mathrm{O}$ & 0.12 \\
\hline 94 & 3-Methylcyclopentanone (Isomer?) & 44.72 & 98 & $\mathrm{C}_{6} \mathrm{H}_{10} \mathrm{O}$ & 0.23 \\
\hline 95 & Furfural & 44.74 & 96 & $\mathrm{C}_{5} \mathrm{H}_{4} \mathrm{O}_{2}$ & 0.04 \\
\hline 96 & (1-Methylethyl)benzene & 44.78 & 120 & $\mathrm{C}_{9} \mathrm{H}_{12}$ & 0.03 \\
\hline 97 & 4-Methylpentanenitrile & 44.97 & 97 & $\mathrm{C}_{6} \mathrm{H}_{11} \mathrm{~N}$ & 0.18 \\
\hline 98 & 4-Ethenyl-1,4-dimethylcyclohexene & 45.06 & 136 & $\mathrm{C}_{10} \mathrm{H}_{16}$ & 0.34 \\
\hline 99 & 4-Hydroxy-4-methyl-2-pentanone & 45.20 & 116 & $\mathrm{C}_{6} \mathrm{H}_{12} \mathrm{O}_{2}$ & 0.11 \\
\hline 100 & Decane & 45.49 & 142 & $\mathrm{C}_{10} \mathrm{H}_{22}$ & 0.12 \\
\hline 101 & 4,5-Dimethyl-2,6-octadiene & 45.56 & 138 & $\mathrm{C}_{10} \mathrm{H}_{18}$ & 0.54 \\
\hline 102 & 2,7-Dimethyl-1,6-octadiene & 45.69 & 138 & $\mathrm{C}_{10} \mathrm{H}_{18}$ & 0.21 \\
\hline 103 & 4-Methyl-3-penten-2-ol & 45.81 & 100 & $\mathrm{C}_{6} \mathrm{H}_{12} \mathrm{O}$ & 0.07 \\
\hline 104 & Indane & 45.88 & 118 & $\mathrm{C}_{9} \mathrm{H}_{10}$ & 0.10 \\
\hline 105 & Propylbenzene & 45.89 & 120 & $\mathrm{C}_{9} \mathrm{H}_{12}$ & 0.03 \\
\hline 106 & 2,6-Dimethyl-2,6-octadiene & 45.96 & 138 & $\mathrm{C}_{10} \mathrm{H}_{18}$ & 0.33 \\
\hline 107 & 1-(Methylethyl)benzene (Isomer?) & 46.11 & 120 & $\mathrm{C}_{9} \mathrm{H}_{12}$ & 0.21 \\
\hline 108 & Ethyl-3-methylbenzene & 46.21 & 120 & $\mathrm{C}_{9} \mathrm{H}_{12}$ & 0.15 \\
\hline 109 & 2-Methyl-2-cyclopentene-1-one & 46.60 & 96 & $\mathrm{C}_{6} \mathrm{H}_{8} \mathrm{O}$ & 0.09 \\
\hline
\end{tabular}


Appendix 1. (cont.)

\begin{tabular}{|c|c|c|c|c|c|}
\hline No. & Compound & Retention time & MW & Formula & $\%$ in VP \\
\hline 110 & 2,5,6-Trimethyl-1,3,6-heptatriene & 46.80 & 136 & $\mathrm{C}_{10} \mathrm{H}_{16}$ & 0.33 \\
\hline 111 & Acetone cyanhydrin (Artifact ?) & 46.86 & 85 & $\mathrm{C}_{4} \mathrm{H}_{7} \mathrm{NO}$ & 1.35 \\
\hline 112 & 1-Methyl-4-(1-methylethyl)cyclohexene & 47.04 & 138 & $\mathrm{C}_{10} \mathrm{H}_{18}$ & 0.23 \\
\hline 113 & 3-(Methylthio)propanal & 47.16 & 104 & $\mathrm{C}_{4} \mathrm{H}_{8} \mathrm{OS}$ & 0.54 \\
\hline 114 & 1,2,3-Trimethylbenzene & 47.25 & 120 & $\mathrm{C}_{9} \mathrm{H}_{12}$ & 0.09 \\
\hline 115 & Limonene & 47.40 & 136 & $\mathrm{C}_{10} \mathrm{H}_{16}$ & 1.52 \\
\hline 116 & Dimethyltrisulfide & 47.47 & 126 & $\mathrm{C}_{2} \mathrm{H}_{6} \mathrm{~S}_{3}$ & 0.11 \\
\hline 117 & 3,4-Dimethyl-2-cyclopenten -1-one & 47.55 & 110 & $\mathrm{C}_{7} \mathrm{H}_{10} \mathrm{O}$ & 0.02 \\
\hline 118 & Formic acid ethenyl ester & 47.85 & 72 & $\mathrm{C}_{3} \mathrm{H}_{4} \mathrm{O}_{2}$ & 0.75 \\
\hline 119 & 2-Hydroxypropanenitrile & 47.90 & 71 & $\mathrm{C}_{3} \mathrm{H}_{5} \mathrm{NO}$ & 0.85 \\
\hline 120 & 1,3,5-Trimethylbenzene & 48.21 & 120 & $\mathrm{C}_{9} \mathrm{H}_{12}$ & 0.03 \\
\hline 121 & Undecane & 48.22 & 156 & $\mathrm{C}_{11} \mathrm{H}_{24}$ & 0.02 \\
\hline 122 & 1-Undecene & 48.26 & 154 & $\mathrm{C}_{11} \mathrm{H}_{22}$ & 0.03 \\
\hline 123 & 5-Ethylbicyclo[2.2.1]-2-heptene & 48.58 & 122 & $\mathrm{C}_{9} \mathrm{H}_{14}$ & 0.09 \\
\hline 124 & Hydroxyacetonitrile & 48.64 & 57 & $\mathrm{C}_{2} \mathrm{H}_{3} \mathrm{NO}$ & 0.14 \\
\hline 125 & Acetolacetate ? & 48.68 & 116 & $\mathrm{C}_{5} \mathrm{H}_{8} \mathrm{O}_{3}$ & 0.20 \\
\hline 126 & Butanethioic acid S-methyl ester & 49.33 & 118 & $\mathrm{C}_{5} \mathrm{H}_{10} \mathrm{OS}$ & 0.43 \\
\hline 127 & 3-Methylbicyclo[3.3.0]oct-2-en-8-one & 49.59 & 136 & $\mathrm{C}_{9} \mathrm{H}_{12} \mathrm{O}$ & 0.25 \\
\hline 128 & 1,3-Propanediol & 49.73 & 76 & $\mathrm{C}_{3} \mathrm{H}_{8} \mathrm{O}_{2}$ & 0.67 \\
\hline 129 & 5-Methyl-1,5-hexadien-3-ol & 49.80 & 112 & $\mathrm{C}_{7} \mathrm{H}_{12} \mathrm{O}$ & 0.12 \\
\hline 130 & 6-Methylbicyclo[3.3.0]-2-en-7-one & 50.28 & 136 & $\mathrm{C}_{9} \mathrm{H}_{12} \mathrm{O}$ & 0.14 \\
\hline 131 & 3-Methylbicyclo[3.3.0]-2-en-6-one & 50.45 & 136 & $\mathrm{C}_{9} \mathrm{H}_{12} \mathrm{O}$ & 0.24 \\
\hline 132 & Isobutylene epoxide? & 50.72 & 72 & $\mathrm{C}_{4} \mathrm{H}_{8} \mathrm{O}$ & 0.49 \\
\hline 133 & Acetyl-5-norbornene? & 51.10 & 136 & $\mathrm{C}_{9} \mathrm{H}_{12} \mathrm{O}$ & 0.26 \\
\hline 134 & Dihydro-2-methyl-3(2H)-furanone ? & 51.65 & 100 & $\mathrm{C}_{5} \mathrm{H}_{8} \mathrm{O}_{2}$ & 0.21 \\
\hline 135 & 1,3,5-Undecatriene & 51.73 & 150 & $\mathrm{C}_{11} \mathrm{H}_{18}$ & 0.24 \\
\hline 136 & 1,6-Heptadien-4-ol ? & 52.43 & 112 & $\mathrm{C}_{7} \mathrm{H}_{12} \mathrm{O}$ & 0.57 \\
\hline 137 & Butanoic acid phenyl ester? & 53.53 & 164 & $\mathrm{C}_{10} \mathrm{H}_{12} \mathrm{O}_{2}$ & 0.11 \\
\hline 138 & Nicotine & 55.22 & 162 & $\mathrm{C}_{10} \mathrm{H}_{14} \mathrm{~N}_{2}$ & 0.02 \\
\hline
\end{tabular}

